\title{
The effect of intraoperative Mitomycin-C in different dose schedule and time of application in Trabeculectomy
}

\author{
Dr. Siddhesh VikramadityaGarg ${ }^{1}$, Dr. Subhash Sharma ${ }^{2}$, Dr. Isha Lohmror ${ }^{3 *}$
}

\author{
${ }^{1}$ Junior Specialist, Upgraded Department of Ophthalmology, SMS Medical College \& Hospital, Jaipur, Rajasthan, India \\ ${ }^{2}$ Visiting Consultant (Retd. Senior Professor \& Head), Upgraded Department of Ophthalmology, SMS Medical College \& Hospital, \\ Jaipur, Rajasthan, India \\ ${ }^{3}$ Resident, Upgraded Department of Ophthalmology, SMS Medical College \& Hospital, Jaipur, Rajasthan, India
}

DOI: $10.36347 /$ sjams.2020.v08i12.027

| Received: 13.12.2020 | Accepted: 24.12.2020 | Published: 26.12.2020

*Corresponding author: Dr. Isha Lohmror

Abstract

Original Research Article

Background: Mitomycin-C used as adjuvant drug to enhance the outcome of trabeculectomies has no established regime regarding ideal site, dose and duration of application. The purpose of this study is to find out and compare the effect of intraoperative Mitomycin-C, in different dose schedule and time of application, emphasis being laid on intraocular pressure (IOP) lowering effect and side effects. Methods: In this prospective study, a total of 38 eyes of 28 patients were randomized into 4 groups: group A \& B with $0.2 \mathrm{mg} / \mathrm{ml}$ and group C \& D with $0.4 \mathrm{mg} / \mathrm{ml} \mathrm{mitomycin-C}$ with one minute application repeated five times and with single five minute application respectively. All eyes undergo trabeculectomy surgery with intraoperative mitomycin-C used as per the group allocated. Surgical success was defined in terms of IOP measurements. Results: All the study groups were effective in lowering the IOP, the percentage reduction being $61.9 \%$ in group $\mathrm{A}, 54.30 \%$ in group $\mathrm{B}, 75.2 \%$ in group $\mathrm{C}, 69.9 \%$ in group $\mathrm{D}(\mathrm{p}<0.05)$. The highest mean change was observed in group $\mathrm{C}$ as compared to group $\mathrm{A}, \mathrm{B} \& \mathrm{D}$. Postoperative bleb score was significantly higher in group D on 18 week followed by group C and A. Surgical success defined in terms of pressure control, all eyes of group $\mathrm{C} \& \mathrm{D}$ attained pressure reduction to $21 \mathrm{mmHg}$ or less without medication whereas in group A, 8 eyes $(88.9 \%)$ and in group B, 6 eyes $(60 \%)$ achieved complete success rate. Postoperative complications occurred more commonly in study groups in which higher concentration of Mitomycin-C was used .There was no major intraoperative complication in any of the groups. Conclusion: From the results, we suggest that the optimum dose and exposure time of Mitomycin-C in trabeculectomy may be $0.2 \mathrm{mg} / \mathrm{ml}, 5$ applications of one minute each without increasing the complication rate.

Keywords: Mitomycin-C, trabeculectomy, intraocular pressure.

Copyright $\left({ }^{\circ} 2020\right.$ The Author(s): This is an open-access article distributed under the terms of the Creative Commons Attribution 4.0 International License (CC BY-NC 4.0) which permits unrestricted use, distribution, and reproduction in any medium for non-commercial use provided the original author and source are credited.

\section{INTRODUCTION}

Trabeculectomy is universally most accepted surgical procedure for glaucoma despite various new surgical methods available nowadays including nonpenetrating filtration surgery and minimally invasive glaucoma surgeries. However, long-term follow-up of primary trabeculectomy indicates that the success of this procedure decreases with time and stabilizes at $67 \%$ by 10 years [1]. The common cause of failure is fibrosis and scarring in the subconjunctival space and bleb areas suggesting that long term success depends on the wound healing response. Therefore, antiproliferative agents are frequently used to modulate tissue reaction after fistulising surgery [2].

Mitomycin-C is the most frequently used adjuvant agent to enhance the outcome of trabeculectomies in both high risk [3, 4] and uncomplicated glaucoma $[5,6]$. Studies have shown that Mitomycin- $\mathrm{C}$ works in a dose and time dependent manner [7]. However, there is no established rationale for the ideal site, concentration, duration and number of applications. In this randomized clinical trial, we evaluate the effect of intraoperative Mitomycin-C in different dose schedule and time of application in trabeculectomy, emphasis being laid on hypotensive effect and toxic effects.

\section{Materials And Methods}

This was a prospective, randomized study performed at a tertiary care government hospital in North India. The study was approved by the institutional ethics committee and was conducted as per the tenets of the declaration of Helsinki. Before commencing the study each patient was acquainted with the investigational nature of the study, risk and 
advantages. All consenting patients willing to participate signed an informed written consent before enrolment.

\section{Participants}

A total of 38 eyes of 28 patients were included in the study. All patients suffering from glaucoma requiring surgery were included in the study with special preference for high risk groups like primary congenital glaucoma, developmental glaucoma, aphakic glaucoma, angle recession glaucoma and patients with darkly pigmented iris and skin. Eyes with coexistent ocular pathologies like active ocular infection, any corneal pathology, coexisting retinal or macular disease were excluded.

\section{Preoperative Evaluation}

All participants underwent a comprehensive ophthalmic evaluation at time of enrolment including baseline IOP of both eyes using Perkin's handheld applanation tonometer, best corrected visual acquity (BCVA), pupil examination, gonioscopy, dilated slit lamp biomicroscopy and fundus evaluation. Also baseline clinical characteristics and demographic data including patient's age, sex, race, previous surgical procedures, number of glaucoma medications were recorded.

All the participants were randomly divided into 4 groups:

Group A: Patients with one minute application of 0.2 $\mathrm{mg} / \mathrm{ml}$ Mitomycin-C repeated five times.

Group B: Patients with single five minute application of $0.2 \mathrm{mg} / \mathrm{ml}$ Mitomycin-C.

Group C: Patients with one minute application of 0.4 $\mathrm{mg} / \mathrm{ml}$ Mitomycin-C repeated five times.

Group D: Patients with single five minute application of $0.4 \mathrm{mg} / \mathrm{ml}$ Mitomycin-C.

\section{Surgical Technique}

All trabeculectomies were performed by a single surgeon. A limbal based conjunctival flap was prepared, with a conjunctival incision $8-10 \mathrm{~mm}$ from the limbus. A half thickness triangular sclera flap, $4 \mathrm{~mm}$ long and $4 \mathrm{~mm}$ wide, and parallel to and hinged at the limbus was dissected. A cellulose sponge of $2 \times 2 \times 5 \mathrm{~mm}$ in size soaked with MMC was placed to the sclera bed, in different concentrations and for different time periods according to the study group. After removal of the cellulose sponge, the wound was irrigated thoroughly with balanced salt solution. A paracentesis opening was made using a side port, a $1 \mathrm{~mm}$ x $3 \mathrm{~mm}$ sclera block beneath the sclera flap was excised and an iridectomy was performed. The sclera flap was closed with three 10-0 nylon sutures, one at the apex and one on each lateral side of the flap. The conjunctival and Tenon's layer were closed with a single running $8-0$ silk suture. combined

In patients with Primary Congenital glaucoma, performed. For this we first performed trabeculectomy using similar technique described above. After this a $2 \times 2 \mathrm{~mm}$ trabeculectomy flap was outlined without penetrating the anterior chamber and a central radial incision was made across the sclera spur to cut the external wall of Schlemm's canal until there is gush of aqueous, occasionally mixed with blood. The internal arm of trabeculotome was introduced into the canal using the external parallel arm as a guide. The trabeculotome is rotated into the anterior chamber. About 2 to $2 \frac{1}{2}$ clock hours of the internal wall of Schlemm's canal and trabecular meshwork are disrupted by the movement of trabeculotome into the anterior chamber. The trabeculotome is then passed in similar fashion on the other side of radial incision and rotated. In total, about 100 to 200 degree of trabecular meshwork is ruptured by this technique. Once the trabeculotomy had been completed, the $2 \times 2 \mathrm{~mm}$ trabeculectomy flap made earlier, was excised and an iridectomy was performed. The sclera flap was closed with 10-0 nylon sutures, the conjunctival and Tenon's layer were closed simultaneously with a single running 8-0 silk suture.

\section{Postoperative Evaluation}

The postoperative regimen consists of topical steroid $1 \%$ prednisolone and antibiotic $0.3 \%$ tobramycin four times daily and homatropine eye drops twice daily; the homatropine was continued at this dose for 4 to 6 weeks and steroids were tapered over a period of 8 to 10 weeks. All patients were followed up regularly for 18 weeks. Initially patients were examined daily for 6 days after surgery and then seen at 6-week intervals for 18 weeks. At every postoperative visit IOP values, BCVA, anterior segment biomicroscopy and the condition of bleb were examined. The complications related to surgery and number of antiglaucoma medications as and when required, were also noted.

\section{Bleb analysis}

A bleb scoring system based on the elevation of the bleb and the extent of the bleb surrounding the limbus was used to give each bleb a numerical score for bleb analysis. The elevation of the bleb was graded on a scale of 0 to 4 . " 0 " indicated a scarred bleb and "4" indicated a highly elevated bleb. The extent of the bleb was graded according to a system using clock hours. " 1 " was indicated by half an hour and " 8 " was indicated by 4 hours etc. Bleb scores were generated by adding the number of clock hours to the bleb elevation score.

Bleb score $=(1)+(2)$

1. = elevation of the bleb

2. = extent of the bleb surrounding the limbus: half hour increments

Thus, a bleb could have a point score from 0.5 to 16 . We considered a bleb to be failed once it reached a score of 1 or less. 


\section{Statistical analysis}

The results are reported as mean $\pm 2 \mathrm{SD}$. All data were entered using Microsoft Excel 2007. Statistical calculations were performed using the Student's t test, median test, chi-square test or ANOVA. The statistical significance level was defined as a $\mathrm{P}$ value of $<0.05$

Surgical success was defined in terms of IOP measurements. The following criteria for successful IOP control were adopted and categorised based on the use of antiglaucoma medication:

- Complete success was achieved when the final IOP was $21 \mathrm{~mm} \mathrm{Hg}$ or less without medication.

- Qualified success was achieved when the final IOP was $21 \mathrm{~mm} \mathrm{Hg}$ with medication.

- Qualified failure was defined when the final IOP was more than $21 \mathrm{~mm} \mathrm{Hg}$ with medication.

- Complete failure was defined when further glaucoma surgery was needed to control IOP.

\section{RESULTS}

38 eyes of 28 patients were randomized into 4 groups. Group A $(\mathrm{n}=9)$ used MMC $0.2 \mathrm{mg} / \mathrm{ml}$ with 1 minute application repeated five times, Group B $(n=10)$ used MMC $0.2 \mathrm{mg} / \mathrm{ml}$ with single 5 minute application. In Group C $(\mathrm{n}=10)$ MMC $0.4 \mathrm{mg} / \mathrm{ml}$ with 1 minute application was repeated five times and in Group D $(\mathrm{n}=9)$ single 5 minute application of $0.4 \mathrm{mg} / \mathrm{ml} \mathrm{MMC}$ was done. The demographic and baseline clinical factors between different groups are shown in Table- 1 . Maximum number of the eyes were in age group 0$10 \mathrm{yrs}(31.57 \%)$, about $57.9 \%(\mathrm{n}=22)$ were below $40 \mathrm{yrs}$ of age, the age incidence was comparable with no statistically significant difference among study groups. In group A \& B, male and female distribution is nearly equal whereas in group $\mathrm{C} \& \mathrm{D}$, majority of patients were male (Table-1). Of total 38 eyes, 12 eyes were with Primary Congenital Glaucoma, 3 eyes with developmental glaucoma(A-R Syndrome), 8 eyes with Primary open angle glaucoma, 8 eyes with Primary angle closure glaucoma, 2 eyes of Aphakic glaucoma, 1 with Angle Recession glaucoma, 3 failed surgery and 1 eye with glaucoma secondary to uveitis (Table-2). All the eyes had preoperative IOP $26 \mathrm{mmHg}$ or more with medication. The mean number of anti glaucoma medications used preoperatively was $2.44,2.20,2.40$ and 2.33 respectively, these were comparable in all the groups. 19(50\%) eyes were treated with three medications, $13(34.2 \%)$ eyes with two medications and $6(15.8 \%)$ eyes with single medication. Postoperatively, no medication was used in eyes of group $\mathrm{C} \& \mathrm{D}$. In group $\mathrm{A}$, one eye and in group $\mathrm{B}, 3$ eyes required medication postoperative. The mean number of medication used in group A was 0.22 and in group B 0.4 , these values did not differ significantly within the four groups. In all the four groups there was highly significant reduction in mean number of medications required postoperatively to control IOP than the mean number of medications required preoperatively $(\mathrm{p}<0.001)($ Table-1).

The preoperative mean IOP in the four groups was $34.44 \mathrm{mmHg}, 38.80 \mathrm{mmHg}, 36.40 \mathrm{mmHg}$ and $37.33 \mathrm{mmHg}$ respectively, which was comparable in all the groups $(p>0.05)$. We found there was marked reduction in IOP on day 6 post operative in all the four groups. After day 6, on each follow up the IOP increased slightly in each group. From $12^{\text {th }}$ week to $18^{\text {th }}$ week this rise in IOP was not significant in group A and group B but there was significant rise in group $\mathrm{C}$ and group D (Table 3 ). In comparison to group $\mathrm{B}$, in group A the reduction of IOP was significantly more at each follow-up whereas in comparison to group $\mathrm{C}$, the reduction of IOP was significantly less. When group A was compared with group D, post operative IOP was not significantly different at successive follow up except at day 6 . The postoperative IOP reduction was significantly less in group B than in all other groups. Groups C and D did not differ significantly (Table-4). All the study groups were effective in lowering the IOP. In group $\mathrm{C}$ the average fall of IOP was $27.4 \mathrm{mmHg}$ from the preoperative value, the percentage reduction being $75.2 \%$. In group D the average fall of IOP was $26.11 \mathrm{mmHg}$ from the preoperative value, the percentage reduction being $69.9 \%$. The mean fall of IOP in group A was $21.33 \mathrm{mmHg}$, the percentage reduction being $61.9 \%$ and in group $\mathrm{B}$ it was $21.1 \mathrm{mmHg}$, percentage reduction being $54.30 \%$. Thus mean change was statistically significant in all the groups $(\mathrm{p}<0.05)$. The highest mean change was observed in group $\mathrm{C}$ as compared to group A, B and D. The minimum mean change was found in group $B$ (Table 3).Table 5 shows postoperative bleb score at each follow-up. We found that on 18 week the bleb score was significantly higher in group $\mathrm{D}$ followed by group $\mathrm{C}$ and group $\mathrm{A}$. In group $\mathrm{B}$ bleb score was significantly lower. The mean values are almost same in group A, C and D at 18 week.

Surgical success defined in terms of pressure control, showed all eyes of group C \& D attained pressure reduction to $21 \mathrm{mmHg}$ or less without medication whereas in group A, 8 eyes $(88.9 \%)$ and in group B, 6 eyes $(60 \%)$ achieved complete success rate. Remaining 1 eye of group A and 3 eyes of group B achieved success in IOP reduction with medications. Only 1 eye of group B failed to achieve IOP $<21 \mathrm{mmHg}$ with or without medication (Table-5). In terms of BCVA, 6(100\%) in group A, 6(85.8\%) in group B, $5(71.41 \%)$ in group $C$ and $5(83.3 \%)$ in group D had stabilized or improved vision. Visual acuity worsened in two eyes of group C, one eye of group B and D each (Table-5). Table-6 shows postoperative complications of each group in detail. There was no major intraoperative complication in any of the groups. 
Table-1: Comparison between demographic and baseline clinical factors between different groups with intra operative mitomycin- $\mathrm{C}$ in different dosage and time schedule

\begin{tabular}{|c|c|c|c|c|}
\hline Variable & $\begin{array}{l}\text { Group A } \\
0.2 \mathrm{mg} / \mathrm{ml} \\
1 \mathrm{mtx5} 5 \mathrm{appl} \\
(\mathrm{n}=9)\end{array}$ & $\begin{array}{l}\text { Group B } \\
0.2 \mathrm{mg} / \mathrm{ml} \\
5 \mathrm{mtx1} \text { appl } \\
(\mathrm{n}=10)\end{array}$ & $\begin{array}{l}\text { Group C } \\
0.4 \text { mg/ml } \\
1 \mathrm{mtx} 5 \mathrm{appl} \\
(\mathrm{n}=10)\end{array}$ & $\begin{array}{l}\text { Group } \\
0.4 \mathrm{mg} / \mathrm{ml} \\
\text { 5mtx1appl }(\mathrm{n}=9)\end{array}$ \\
\hline Age (years) & & & & \\
\hline $0-10$ & 3 & 3 & 3 & 3 \\
\hline $11-40$ & 2 & 3 & 3 & 2 \\
\hline Above 40 & 4 & 4 & 4 & 4 \\
\hline Range & $9 \mathrm{~m}-85 \mathrm{yrs}$. & $9 \mathrm{~m}-60 \mathrm{yrs}$. & $25 \mathrm{~d}-65 \mathrm{yrs}$ & $25 \mathrm{~d}-66 \mathrm{yrs}$. \\
\hline Gender (\% men) & $4(44.4 \%)$ & $4(40 \%)$ & $7(70 \%)$ & $7(77.8 \%)$ \\
\hline Preoperative IOP $(\mathrm{mm} \mathrm{Hg})$ & $34.44+7.84$ & $38.80+9.91$ & $36.40+6.96$ & $37.33+7.35$ \\
\hline Preoperative Antiglaucoma medication(Mean/SD) & $2.44+0.726$ & $2.20+0.789$ & $2.40+0.70$ & $2.33+0.90$ \\
\hline Postoperative Antiglaucoma medication(Mean/SD) & $0.22+0.667$ & $0.40+0.700$ & $0.00+0.00$ & $0.00+0.00$ \\
\hline $\begin{array}{l}\text { Mean Change in Pre \&Postop.(3m) no. of } \\
\text { Medication(Mean/SD) }\end{array}$ & $\begin{array}{l}2.22+1.09 \\
\mathrm{p}<0.001\end{array}$ & $\begin{array}{l}1.8+1.03 \\
\mathrm{p}<0.001\end{array}$ & $\begin{array}{l}2.4+0.70 \\
\mathrm{p}<0.001\end{array}$ & $\begin{array}{l}2.4+0.70 \\
\mathrm{p}<0.001\end{array}$ \\
\hline
\end{tabular}

Table-2: Application of Mitomycin-C and type of glaucoma

\begin{tabular}{|l|l|l|l|l|}
\hline Type of Glaucoma & $\begin{array}{l}\text { Group A } \\
\text { 0.2 mg/ml } \\
\text { 1mtx5appl }\end{array}$ & $\begin{array}{l}\text { Group B } \\
\text { 0.2 mg/ml } \\
\text { 5mtx1appl }\end{array}$ & $\begin{array}{l}\text { Group C } \\
\text { 0.4 mg/ml } \\
\text { 1mtx5appl }\end{array}$ & $\begin{array}{l}\text { Group D 0.4mg/ml } \\
\text { 5mtx1appl }\end{array}$ \\
\hline Primary Congenital G & 3 & 3 & 3 & 3 \\
\hline Developmental G(A-R Syndrome) & 0 & 0 & 1 & 2 \\
\hline POAG & 2 & 3 & 1 & 2 \\
\hline PACG & 2 & 2 & 2 & 2 \\
\hline Aphakic G & 1 & 0 & 1 & 0 \\
\hline Angle Recession G & 0 & 1 & 0 & 0 \\
\hline Failed Surgery & 1 & 1 & 1 & 0 \\
\hline Secondary to Uveitis & 0 & 0 & 1 & 0 \\
\hline
\end{tabular}

POAG: Primary open angle glaucoma

PACG: Primary angle closure glaucoma

G: Glaucoma

A-R: Axenfeld-Rieger

Table-3: Comparison between Pre and Post Operative IOP (At each follow up)

\begin{tabular}{|c|c|c|c|c|}
\hline $\begin{array}{l}\text { IOP }(\mathbf{m m ~ H g}) \\
\text { Mean +SD }\end{array}$ & $\begin{array}{l}\text { Group A } \\
\text { 0.2 mg/ml } \\
\text { 1mtx5appl } \\
(\mathrm{n}=9)\end{array}$ & $\begin{array}{l}\text { Group B } \\
\text { 0.2 mg/ml } \\
5 \mathrm{mtx1} \text { lappl } \\
(\mathrm{n}=10)\end{array}$ & $\begin{array}{l}\text { Group C } \\
0.4 \\
\text { mg/ml } \\
1 \mathrm{mtx5ap} \\
\text { pl } \\
(\mathrm{n}=10)\end{array}$ & $\begin{array}{l}\text { Group D } 0.4 \mathrm{mg} / \mathrm{ml} \quad 5 \mathrm{mtx1appl} \\
(\mathrm{n}=9)\end{array}$ \\
\hline Pre operative & $34.44+7.84$ & $38.8+9.91$ & $36.4+6.96$ & $37.33+7.35$ \\
\hline Post operative day 6 & $8.89+1.67$ & $13.83+3.19$ & $6.6+1.35$ & $6.89+1.45$ \\
\hline Post op. 6 week & $10.67+3.04$ & $15.9+4.15$ & $6.8+1.87$ & $8.55+1.94$ \\
\hline Post op.12 week & $12.89+3.85$ & $17.9+5.44$ & $7.8+2.10$ & $10.33+2.83$ \\
\hline Post op. 18 week & $13.11+2.03$ & $17.7+2.50$ & $9.0+2.90$ & $11.22+3.27$ \\
\hline Mean changes (pre \& postop. 18 week) & $21.33+7.57$ & $21.1+9.41$ & $27.4+7.43$ & $26.11+7.47$ \\
\hline $\mathrm{p}$ value & $<0.05$ & $<0.05$ & $<0.05$ & $<0.05$ \\
\hline Significance & $\mathrm{S}$ & S & $\mathrm{S}$ & $\mathrm{S}$ \\
\hline Percent reduction & 61.9 & 54.3 & 75.2 & 69.9 \\
\hline
\end{tabular}


Table-4: Comparative values of IOP changes (Pre and Post Operative at each Follow-up)

\begin{tabular}{|c|c|c|c|c|c|c|}
\hline IOP & $\begin{array}{c}\text { Group } \\
\text { A to B }\end{array}$ & $\begin{array}{l}\text { Group } \\
\text { A to } C\end{array}$ & $\begin{array}{l}\text { Group } \\
\text { A to D }\end{array}$ & $\begin{array}{l}\text { Group } \\
\text { B to C }\end{array}$ & $\begin{array}{l}\text { Group } \\
\text { B to D }\end{array}$ & $\begin{array}{r}\text { Group } \\
\text { C to D }\end{array}$ \\
\hline & $\begin{array}{l}\text { p value } \\
\text { S/NS }\end{array}$ & $\begin{array}{l}\mathrm{p} \text { value } \\
\text { S/NS }\end{array}$ & $\begin{array}{l}\mathrm{p} \text { value } \\
\text { S/NS }\end{array}$ & $\begin{array}{l}\mathrm{p} \text { value } \\
\text { S/NS }\end{array}$ & $\begin{array}{l}\mathrm{p} \text { value } \\
\text { S/NS }\end{array}$ & $\begin{array}{l}\mathrm{p} \text { value } \\
\text { S/NS }\end{array}$ \\
\hline Preop. & $\begin{array}{l}>0.05 \\
\mathrm{NS}\end{array}$ & $\begin{array}{l}>0.05 \\
\text { NS }\end{array}$ & $\begin{array}{l}>0.05 \\
\text { NS }\end{array}$ & $\begin{array}{l}>0.05 \\
\text { NS }\end{array}$ & $\begin{array}{l}>0.05 \\
\text { NS }\end{array}$ & $\begin{array}{l}>0.05 \\
\text { NS }\end{array}$ \\
\hline 6 day & $\begin{array}{l}<0.001 \\
\mathrm{~S}\end{array}$ & $\begin{array}{l}<0.001 \\
\mathrm{~S}\end{array}$ & $\begin{array}{l}<0.01 \\
\mathrm{~S}\end{array}$ & $\begin{array}{l}<0.001 \\
\mathrm{HS}\end{array}$ & $\begin{array}{l}<0.001 \\
\mathrm{HS}\end{array}$ & $\begin{array}{l}>0.05 \\
\mathrm{NS}\end{array}$ \\
\hline 6 week & $\begin{array}{l}<0.01 \\
\text { HS }\end{array}$ & $\begin{array}{l}<0.02 \\
\mathrm{~S}\end{array}$ & $\begin{array}{l}>0.05 \\
\mathrm{NS}\end{array}$ & $\begin{array}{l}<0.001 \\
\mathrm{HS}\end{array}$ & $\begin{array}{l}<0.001 \\
\mathrm{HS}\end{array}$ & $\begin{array}{l}>0.05 \\
\text { NS }\end{array}$ \\
\hline 12 week & $\begin{array}{l}<0.01 \\
\mathrm{~S}\end{array}$ & $\begin{array}{l}<0.01 \\
\mathrm{~S}\end{array}$ & $\begin{array}{l}>0.05 \\
\text { NS }\end{array}$ & $\begin{array}{l}<0.001 \\
\mathrm{HS}\end{array}$ & $\begin{array}{l}<0.01 \\
\mathrm{HS}\end{array}$ & $\begin{array}{l}<0.05 \\
\mathrm{~S}\end{array}$ \\
\hline 18 week & $\begin{array}{l}<0.001 \\
\mathrm{~S}\end{array}$ & $\begin{array}{l}<0.01 \\
\mathrm{~S}\end{array}$ & $\begin{array}{l}>0.05 \\
\mathrm{NS}\end{array}$ & $\begin{array}{l}<0.001 \\
\mathrm{HS}\end{array}$ & $\begin{array}{l}<0.001 \\
\text { AS }\end{array}$ & $\begin{array}{l}>0.05 \\
\mathrm{NS}\end{array}$ \\
\hline
\end{tabular}

Table-5: Comparison of Post Operative outcomes between different groups

\begin{tabular}{|c|c|c|c|c|c|c|c|}
\hline \multicolumn{2}{|l|}{ Variable } & \multirow{2}{*}{$\begin{array}{l}\begin{array}{l}\text { Group A } \\
\text { 0.2 } \mathbf{~ m g / m l} \\
\text { 1 mtx5appl } \\
(\mathbf{n}=9)\end{array} \\
6.78+1.56\end{array}$} & \multirow{2}{*}{$\begin{array}{l}\begin{array}{l}\text { Group B } \\
\text { 0.2 mg/ml }\end{array} \\
\begin{array}{l}\text { 5mtx1appl } \\
(\mathbf{n}=10)\end{array} \\
5.60+0.966\end{array}$} & \multirow{2}{*}{$\begin{array}{l}\begin{array}{l}\text { Group C } \\
\text { 0.4 } \mathbf{~ m g / m l} \\
\text { 1mtx5appl } \\
(\mathbf{n}=\mathbf{1 0})\end{array} \\
7.10+1.28\end{array}$} & \multicolumn{3}{|c|}{$\begin{array}{l}\text { Group D 0.4mg/ml 5mtx1appl } \\
(\mathrm{n}=9)\end{array}$} \\
\hline \multirow[t]{4}{*}{$\begin{array}{l}\text { Post operative } \\
\text { Bleb Score }\end{array}$} & $\begin{array}{l}\text { Postop. } \\
\text { Day } 6\end{array}$ & & & & $6.6+0.726$ & $\begin{array}{l}\text { Fvalue } \\
3.00\end{array}$ & $\begin{array}{l}\text { Pvalue } \\
<0.05\end{array}$ \\
\hline & Week 6 & $6.67+0.707$ & $5.10+1.20$ & $6.80+0.790$ & $6.30+0.870$ & 7.088 & $<0.05$ \\
\hline & Week12 & $6.44+0.726$ & $5.00+1.41$ & $6.50+0.850$ & $6.44+0.882$ & 5.110 & $<0.05$ \\
\hline & Week18 & $6.22+0.667$ & $5.00+1.41$ & $6.30+0.823$ & $6.33+1.0$ & 3.886 & $<0.05$ \\
\hline \multirow{2}{*}{$\begin{array}{l}\text { Success rate } \\
\text { defined by IOP } \\
\text { control }\end{array}$} & Complete Success & $8(88.9 \%)$ & $6(60 \%)$ & $10(100 \%)$ & \multicolumn{3}{|l|}{$9(100 \%)$} \\
\hline & $\begin{array}{l}\text { Complete Success+ } \\
\text { Qualified Success }\end{array}$ & $9(100 \%)$ & $9(90 \%)$ & $10(100 \%)$ & \multicolumn{3}{|l|}{$9(100 \%)$} \\
\hline \multirow[t]{2}{*}{ BCVA Postop. } & Stabilised/improved & $6(100 \%)$ & $6(85.8 \%)$ & $5(71.4 \%)$ & \multicolumn{3}{|l|}{$5(83.3 \%)$} \\
\hline & Worse & $0(0.0 \%)$ & $1(14.2 \%)$ & $2(28.6 \%)$ & \multicolumn{3}{|l|}{$1(16.7 \%)$} \\
\hline
\end{tabular}

Table-6: Post Operative Complications of each Group

\begin{tabular}{|c|c|c|c|c|}
\hline & $\begin{array}{l}\text { Group A } 0.2 \mathrm{mg} / \mathrm{ml} \\
\text { 1mtx5appl }(\mathrm{n}=9)\end{array}$ & $\begin{array}{l}\text { Group B } 0.2 \mathrm{mg} / \mathrm{ml} \\
\text { 5mtx1appl }(\mathrm{n}=10)\end{array}$ & $\begin{array}{lcr}\text { Group } & \text { C } & 0.4 \\
\text { mg/ml } & \text { 1mtx5appl } \\
(\mathrm{n}=10) & & \\
\end{array}$ & $\begin{array}{l}\text { Group D 0.4mg/ml } \\
\text { 5mtx1appl }(\mathrm{n}=9)\end{array}$ \\
\hline $\begin{array}{l}\text { Early complications } \\
\text { Hyphema }\end{array}$ & $1(11.1 \%)$ & $1(10 \%)$ & $1(10 \%)$ & $0(0.0 \%)$ \\
\hline Corneal epi. defect & $0(0.0 \%)$ & $1(10 \%)$ & $1(10 \%)$ & $2(22.2 \%)$ \\
\hline Conj. Wound leak & $1(11.1 \%)$ & - & $1(10 \%)$ & - \\
\hline Shallow A/C & $1(11.1 \%)$ & $1(10 \%)$ & $4(40 \%)$ & $3(33.3 \%)$ \\
\hline Choroid detachment & $1(11.1 \%)$ & - & $3(30 \%)$ & $1(11.1 \%)$ \\
\hline $\begin{array}{l}\text { Late complications } \\
\text { Persistent Hypotony }\end{array}$ & - & - & $2(20 \%)$ & $1(11.1 \%)$ \\
\hline Hypotony Maculopathy & - & - & $2(20 \%)$ & $1(11.1 \%)$ \\
\hline
\end{tabular}

\section{DISCUSSION}

In this randomized study, we studied the effect of intraoperative Mitomycin-C in different dose schedule and time of application in trabeculectomy. We found that postoperative significant complications occurred more commonly in study groups in which higher concentration of Mitomycin-C was used i.e. Group C \& D and because there was no difference among the Group A, C \& D in success rate, regardless of medication, we suggest that the optimum dose and exposure time of Mitomycin-C in trabeculectomy may be $0.2 \mathrm{mg} / \mathrm{ml}, 5$ applications of one minute each.
Trabeculectomy in elderly patients and combined trabeculotomy-trabeculectomy in children are the most efficacious and cost effective long-term method of treating glaucoma in most developing countries. However standard trabeculectomy is thought to be less successful in dark pigmented eyes [8], with success rate of $80-90 \%$ in primary open angle glaucoma [9] and probably less than 50\% in secondary glaucomas [10]. Several clinical studies [3-6, 11, 12] have shown that this success rate of trabeculectomy, in both complicated and uncomplicated glaucomas, can be improved with the use of Mitomycin-C. Different dosages, time of exposure and methods of application 
of Mitomycin-C have been proposed in various studies $[7,13,14]$.

In this study, we intend to find out the ideal concentration and exposure time of mitomycin- $\mathrm{C}$ for maximum hypotensive effect with minimum complications. Total 38 eyes of 28 patients were divided into 4 groups Group A\&B $0.2 \mathrm{mg} / \mathrm{ml}$ and Group C\&D $0.4 \mathrm{mg} / \mathrm{ml}$ concentration with exposure time of 1 minute repeated five times in Group A\&C and single 5 minute application in Group B\&D. The rationale behind using 5 applications of 1 minute each is that constant 5 minute single application might lead to gradual diminution of concentration of MMC during the procedure due to accumulation of tissue fluid, blood etc from sclera, conjunctiva and tenon's. This would decrease the effect of that particular concentration of drug. We enrolled low risk cases as well as high risk cases in our study.

The preoperative clinical data of the four groups were more or less similar. Postoperatively, all the four groups were effective in marked reduction of IOP on postoperative day 6 . After day 6 , slight increase in mean IOP was present up to the end of 18 week, this rise in IOP was comparable in the four groups. The hypotensive effect was maintained in all the groups throughout the study period. The pressure reduction was $61.9 \%$ in Group A, $54.30 \%$ in Group B, $75.2 \%$ in Group C and $69.9 \%$ in Group D at the end of 18 week study. The reduction of IOP in Group A was more than found in Lee JJ et al., [12] whereas in Group D the reduction of IOP was similar to Lee [12] and Ramakrishnan et al., [15]. In our study, 1 eye of Group $\mathrm{A}$ and 3 eyes of Group B required postoperative medications for IOP control as defined by an IOP of $21 \mathrm{mmHg}$ or less. These results of Group B\&D are in accordance to Lee et al., [12]. We find that in all the 4 groups there was highly significant reduction in mean number of medications required postoperatively to control IOP than the mean number of preoperative medication.

The mean bleb scores were almost same in Group A, C\&D but in Group B the bleb score was significantly lower. All the eyes of the four groups had well formed blebs with good bleb scores except one eye from Group B which developed scarring of bleb. Similar results were reported by Lee JJ et al., [12] who took the same criteria for defining bleb score. $100 \%$ eyes of Group A, 85.8\% of Group B, 83.3\% of Group D and $71.4 \%$ eyes of Group $\mathrm{C}$ had stabilized or improved postoperative visual acquity. The results are similar to as found in Lee JJ et al., [12], Mietz $\mathrm{H}$ et al., and Ramakrishnan et al., [15] studies.

Complete success (i.e. without medication), in reducing IOP was achieved by $100 \%$ eyes of Group C $\&$ D, $88.9 \%$ eyes of Group A and $60 \%$ eyes of Group B. The complete and qualified success (i.e. with medication) was achieved by $100 \%$ eyes of Group A and $90 \%$ of Group B. Only one eye of Group B failed to have controlled IOP with or without medication. Our results in Group B are comparable to studies done by Palmer [3] with $84 \%$ success rate, Chen et al., [16] with $79.1 \%$, Mermound et al., [4] with $83 \%$ and Long $\mathrm{M}$ et al., who reported $84 \%$ success rate taking the same concentration and exposure time of mitomycin-C. Our results in Group D are also in line with Chen et al., [16] $100 \%$, Lee [12] $100 \%$ and Ramakrishnan [15] 93.4\% success rate taking almost similar criteria of study.

Postoperative significant complications occurred more commonly in study groups in which higher concentration of Mitomycin-C was used i.e. Group C\&D. Shallow anterior chamber was found in $4(40 \%)$ eyes of Group C, 3(33.3\%) eyes of Group D, $1(11.1 \%)$ eye of Group A and $1(10 \%)$ eye of Group B. Choroidal detachment was observed in $3(30 \%)$ eyes of Group C, 1(11.1\%) eye of Group A and D. Hyphema, conjunctival wound leak and corneal epithelial defects were the other complications found during the early postoperative period but failed to show any predilection to a particular group. Our study Group B differs from Megavend et al., [17] and Group D from Ramakrishnan et al., [15] in terms of persistent hypotony and hypotony maculopathy. Study Group B \& D correlate well with study conducted by Lee JJ et al., [12] showing similar rate of these complications.

Our study has limitations. As the number of cases studied were rather small and the period of observation was also limited, long term observation of a large number of cases are needed to support our study and for better understanding of pharmacokinetics involved in the use of Mitomycin-C for glaucoma surgery.

\section{Conclusion}

From the results, it appears that $0.2 \mathrm{mg} / \mathrm{ml}$ of intraoperative Mitomycin-C, 5 applications of one minute each, is quite efficacious for treating both complicated and uncomplicated trabeculectomy without increasing the complication rate. However, further studies are necessary to maximize the application of this drug in filtration surgery.

\section{REFERENCES}

1. Chen TC, Wilensky JT, Viana MA. Long-term follow-up of initially successful trabeculectomy. Ophthalmology. 1997; 104(7):1120-1125.

2. Matlach J Panidou E Grehn F Large-area versus small-area application of mitomycin $\mathrm{C}$ during trabeculectomy. Eur J Ophthalmol. 2013; 23: 670677.

3. Palmer SS. Mitomycin as adjuvant chemotherapy with trabeculectomy. Ophthalmology 1991; 98:317-321. 
4. Mermoud A, Salmon JF, Murray AND. Trabeculectomy with mitomycin-C for refractory glaucoma in blacks. Am J Ophthalmol.1993; 116:72-78.

5. Krupin TH, Juzych MS, Shin DH, Khatana AK, Olivier MMG, Adjunctive mitomycin-C in primary trabeculectomies in phakic eyes. Am J Ophthalmol.1995; 119:30-39.

6. Kitazawa Y, Suemori-Matsushita H, Yamamoto T, Kawase K. Low-dose and high-dose mitomycin trabeculectomy as an initial surgery in primary open-angle glaucoma. Ophthalmology 1993; 100:1624-1628.

7. Yamamoto T, Varani J, Soong HK, Lighter PR. Effects of 5-fluorouracil and mitomycin $\mathrm{C}$ on cultured rabbit subconjunctival fibroblasts. Ophthalmology. 1990 Sep 1;97(9):1204-10.

8. Miller RD, Barber IC. Trabeculectomy in black patients. Ophthalmic Surg. 1981; 12:46.

9. Richardson KT. Surgical control of chronic open angle glaucoma. In symposium on glaucoma. Transactions of the new Orleans Academy of Ophthalmology. St Louis, CV Mosby CO. 1975; P275.

10. Heuer DK, Gressel MG, Parrish RK, Anderson DR. Trabeculectomy in aphakic eyes. Ophthalmology.1984; 91:1045

11. Chen CW. Enhanced IOP controlling effectiveness of trabeculectomy by local application of
Mitomycin-C. Trans. Asia-Pacific Acad. Ophthalmol. 1983; 9:172

12. Lee JJ, Park KH, Yong DH. The effect of low and high dose adjunctive mitomycin-C in trabeculectomy. Korean J Ophthalmology. 1996; $10: 42$.

13. Jampel HD. Effect of brief exposure to mitomycin $\mathrm{C}$ on viability and proliferation of cultured human Tenon's capsule fibroblasts. Ophthalmology. 1992; 99(9):1471-1476.

14. Al Habash A, Aljasim LA, Owaidhah O, Edward DP. A review of the efficacy of mitomycin $\mathrm{C}$ in glaucoma filtration surgery. Clinical Ophthalmology (Auckland, NZ). 2015;9:19451951.

15. Ramakrishnan R, Michon J, Robin AL, Krishnadas R. Safety and efficacy of Mitomycin$\mathrm{C}$ trabeculectomy in southern India. A short term pilot study. 1993; 100:1619.

16. Chen CW, Huang HT, Bair JS, Lee JJ. Trabeculectomy with simultaneous topical application of mitomycin-C in refractory glaucoma. J Ocular Pharmacol. 1991; 6:175.

17. Megavend GS, Salmon JF, Scholtz RP, Murry $\mathrm{AD}$. The effect of reducing the exposure time of mitomycin-C in glaucoma filtering surgery. Ophthalmology. 1995; 102:84. 